\title{
THE DEVELOPMENT OF RIGHTS OF ELECTRONIC MEDIA THROUGH THE DEVELOPMENT OF COPYRIGHT LAWS IN SERBIA
}

\author{
UDC 316.774:347.78(497.11)
}

\section{Andrej Blagojević}

Faculty of Philosophy, University of Niš, Serbia

\begin{abstract}
The paper aims to present the development of national legislative acts on copyright and related rights in the field of broadcasting, by focusing on the copyright norms directly related to electronic media. The goal will be achieved by providing a chronological overview and normative analysis of all legislative act son copyright and related rights adopted thus far, starting from the 1929 Copyright Act of the Kingdom of Yugoslavia to the current Act on Copyright and Related Rights of the Republic of Serbia. After presenting the initial premises, the author analyzes the norms related to electronic media (radio and television), covering the period from the adoption of the 1929 Copyright Act of the Kingdom of Yugoslavia to the 2004 Act on Copyright and Related Rights of the Republic of Serbia. Then, the article provides an overview of the copyright norms related to electronic media in the positive law by analyzing the 2009 Act on Copyright and Related Rights and its subsequent amendments. The results of this analysis should indicate the significant impact of electronic media in the process of regulating copyright issues throughout the history of national copyright law as well as in the positive copyright law.
\end{abstract}

Key words: electronic media, radio, television, copyright, Act on Copyright and Related Rights

\section{INTRODUCTION}

The technical and technological development in the world has brought both positive and negative consequences in the field of intellectual property. The positives ones are reflected in the new forms of authorship and availability of these works to a wide audience, as well as in the development of new rights related to copyright. However, it has also brought negative consequences in terms of finding new ways to violate these rights, which ultimately calls for their more dynamic and expanded protection. The development of radio and television, and then the Internet, contributed greatly to such consequences. Although

Received November $20^{\text {th }} 2020$ / Accepted November $26^{\text {th }} 2020$

Corresponding author: Andrej Blagojević, Teaching Assistant, Communicology and Journalism Department, Faculty of Philosophy, University of Niš, Republic of Serbia. E-mail: andrej.blagojevic@ filfak.ni.ac.rs 
the contemporary conditions of media convergence have made the Internet the most suitable platform for frequent and extensive copyright violations, the focus of this paper will be on electronic media, i.e. the relevant provision of former and current legislation on copyright and related rights pertaining to electronic media. Pursuant to Article 4 of the Electronic Media Act, ${ }^{1}$ the concept of electronic media includes radio and television programs, as well as program content available on demand by electronic communication networks and the content of electronic publications (Article 4 (1) EMA). Nevertheless, for the purposes of this analysis, the term electronic media will be considered in a narrower sense, and limited to the provisions relating to the rights, obligations and services of radio and television stations.

Significant efforts in regulating copyright and related rights began in the second half of the $20^{\text {th }}$ century, which was certainly in favour of the copyright owners. However, over time, the essence of protecting the original copyright ownership has been lost in favor of companies (corporations), which now act as copyright controllers and custodians of culture in popular media, which can be seen as a transition from personal to corporate copyright (Cvetkovski, 2013:55). In a way, it may imply that the author's moral rights, as opposed to property rights, were pushed to the background. The commercialization of intellectual property rights has become a significant segment of income of companies and corporations. It also refers to electronic media, as evidenced by the fact that the BBC (British Broadcasting Corporation), the British public service broadcaster, earned 32 million pounds from royalties in 2019 alone (BBC Group, 2020: 177). ${ }^{2}$ In order for electronic media (such as television and radio stations) to generate such revenues, there is a need for comprehensive protection against unauthorized broadcasting of their programs and signals. The protection of radio and television stations, as well as the third parties as authors of radio and television programs or contents, includes a complex combination of several different intellectual property rights, including the copyright pertaining to audiovisual works (musical works, television works) and related rights (rights of phonogram producers, videogram producers, and broadcast producers), as well as the industrial property rights (know-how, competition rights, trademarks, industrial design, and business name). This paper will focus on the norms related to the protection of radio and television broadcasting as well as the norms regulating the protection of the holders of copyright and related rights concerning these broadcasts.

\section{HistoricAl DEVELOPMENT OF Rights RELATED to ElECTRONIC MEDIA THROUGH THE DEVELOPMENT OF COPYRIGHT LEGISLATIVE ACTS IN SERBIA FROM 1929 TO 2009}

Although the first national regulations related to industrial property were passed in the $19^{\text {th }}$ century, the Austrian Copyright Law of 1895 and the Hungarian Copyright Law of 1881 were valid until 1929 in different parts of the Kingdom of Serbs, Croats and Slovenes, which were previously part of the Austro-Hungarian Monarchy The first legislative act regulating the field of copyright law was passed in 1929in the Kingdom of Yugoslavia (Pustišek, 1987:132) The next two parts of the paper provide a chronological overview of the development of rights related to radio and television organizations in Serbia by

\footnotetext{
${ }^{1}$ The Electronic Media Act (EMA), Official Gazette of Republic of Serbia, no. 83/2014 and 6/2016-other act)

${ }^{2}$ BBC Group (2020): Annual Report and Accounts 2019/20
} 
examining the legislative acts on copyright law from the adoption of the first copyright act in 1929 until the present day.

\subsection{The Copyright Act of 1929}

The first Copyright Protection Act of the Kingdom of Yugoslavia (1929) ${ }^{3}$ was largely influenced by the Berne Convention for the Protection of Literary and Artistic Works (1886), the most significant regulation in this area at the time. In addition to Article 3 (item 6) of this CPA which envisages the protection of the exclusive rights of authors of original cinematographic works, this Act directly refers to radio broadcasts in only one article. Article 22 (item 8 ) provides for the right of "transmission and public performance of literary or artistic works by radio-electronic means of communication." This Article actually refers to the exclusive rights of authors of these works to distribute, publish, publically present, transfer the right or issue a licence for public performance (Article 21) while the rights related to broadcasting organizations did not exist at the time. Yet, there was an emerging issue concerning the payment of copyright remuneration by radio license users that broadcast radio programs in the course of their business activities, which led to the emergence of the first tariffs on broadcast licenses (Pustišek, 1987: 144).

\subsection{The Copyright Act of 1946}

The Copyright Act of the FPRY (1946) 4 was among the first legislative acts enacted after the constitution of the Federal People's Republic of Yugoslavia. Although it was not directly related to radio stations, certain provisions indirectly apply to them. Thus, Article 4 of this Act prescribes the following authorship rights: the right to publish, adapt, reproduce, present, perform and translate one's work, as well as the right to remuneration if these activities are taken by another person or the state without the author's permission (Article 4). Under Article 14, if dramatic, musical, dramatic-musical, cinematographic, pantomime, choreographic, and similar works have already been published, they may be shown and performed without the author's explicit permission but the author is entitled to receive relevant remuneration. Article 16 (item 13) states that there will be no copyright infringement if it is a matter of "literal excerpt citation" from the published work, provided that the citation does not exceed one third of the work where the citation is being used.

\subsection{The Copyright Act of 1957}

When compared to its predecessors, the next Copyright Act $(1957)^{5}$ had a form reminiscent of modern legal regulations in this area. It had three times more articles than its predecessor, distributed in eight chapters. Its content was also more comprehensive than the previous one, expanding and elaborating on certain copyright institutes. The copyright provisions referred not only to radio but also indirectly to television programs, even though the regular television program in Serbia started in 1958. Pursuant to Article 30 (items 1,2) of this Act, authors of dramatic, dramatic-musical and musical works have the exclusive right to grant permission for the public presentation, performance, and broadcasting of their works. Article 31 specifies the author's exclusive right to grant permission for: "1) broadcasting

\footnotetext{
${ }^{3}$ The Copyright Protection Act, Official Gazette of the Kingdom of Yugoslavia, no. 304/1929.

${ }^{4}$ The Copyright Protection Act, Official Journal of the FPRY, no. 45/1946.

${ }^{5}$ The Copyright Act, Official Journal of the FPRY, no. 36/1957.
} 
his/her work on the radio or communicating it to the public by any other means of wireless transmission of signs, sounds, or images; 2) communicating to the public, by wired or wireless means, a work broadcast over the radio, in case the broadcast is not made by the institution that initially broadcast it over the radio, but by another institution; and 3 ) communicating to the public, via a loudspeaker or a similar device for the transmission of signs, sound, or images, a part of work which has been broadcast over the radio" (Article 31). Article 32 refers to the author's right to authorize the recording, performance and public transmission of their work by mechanical reproduction devices. Article 33 is the first provision in the legal regulation of this area that directly refers to broadcasting institutions. It states that "a broadcasting institution may record, with its own funds, and only for its own purposes broadcast the protected works for which it has received a broadcasting license, and may retransmit the recordings subject to paying a fee and without obtaining a new permission from the author and other authorized persons, unless otherwise agreed" (Article 33, para.2). Article 34 envisages that broadcasting institutions may broadcast the works recorded by means of mechanical reproduction devices even without the author's permission, but they are obliged to fully observe all rights of the author and other authorized persons. The fact that this Act has some modern features may be supported by Article 42, which envisages the suspension of exclusive authorship rights in case of publishing information on current newsworthy events of public importance in the press and by broadcasting, whereby the author is given the possibility to compile a collection of works that are subject to such suspension. Article 74 envisages that the copyright protection institution is entitled to initiate a copyright protection dispute before the competent courts and other state bodies even without obtaining a special authorization from the author if he/she is member of the national association of authors or a foreign citizen whose rights are protected by the institution (Article $74 \mathrm{CA}$ ).

The Act amending the Copyright Act $(1965)^{6}$ was enacted as a result of changing the name of the state into the SFRY. The enacted changes were cosmetic rather than essential. Some more significant changes, envisaged in Article 11-14 of this Act, refer to the greater autonomy of associations that are in charge of exercising copyright-related rights.

\subsection{The Copyright Act of 1968}

Although the Copyright Act (1968) ${ }^{7}$ was significantly broader in terms of broadcasting norms than its predecessor, there were no significant changes compared to the previous Act. Most of the articles that are at least indirectly related to broadcasting were envisaged in the chapter that refers to exercising copyright-related rights (Articles 31-39). While most articles remained unchanged, Article 32 envisaged that the authors of dramatic, musical and dramatic-musical works also have the exclusive right to authorize the translation in the course of public presentation and public performance of their works broadcasting their presentation and performance by any means (Article 32, para.2 CA). Other significant articles are those related to authorship agreements regulating the transfer of authorship rights to another. Thus, Article 56 states that the subject matter of agreement may be the broadcasting of the author's work via radio or television, recording by audio-visual devices, adapting the work or granting translation rights. Moreover, Article 58 envisages that a special

\footnotetext{
${ }^{6}$ The Act amending the Copyright Act, Official Journal of the SFRY, no. 11/1965.

${ }^{7}$ The Copyright Act, Official Journal of the SFRY, no. 30/1968.
} 
agreement must be concluded between the authors and broadcasting institutions in case of public presentation and public performance of non-stage musical and literary works.

\subsection{The Copyright Act of 1978}

Following the adoption of the new 1974 Constitution of the SFRY, the new Copyright Act $(1978)^{8}$ was enacted ten years after the adoption of the previous one and remained in force (with some amendments) for two subsequent decades. The 1974 Constitution was the basis forth terminological change of broadcasting institutions, which were now designated as "broadcasting organizations of associated labor". Apart from that, there are very few changes in the legal provisions on broadcasting. The articles regulating this matter are identical to the articles of the previous legislative acts. Yet, we may mention some new developments. Article 15 envisages that the authors of cinematographic works have, inter alia, the exclusive right to record, reproduce, present, adapt and broadcast their works by radio broadcasting. Article 21 (para.2) stipulates that the organization of associated labor (including a broadcasting organization) has the exclusive right to use the work created by an employee (worker) in the course of employment for a limited period of five years, without obtaining the employee's permission, but the employee (author) is entitled to receive a remuneration, depending on the contribution of his/her work to the overall performance.

When compared to the previous legislative act, it should be noted that the subject matter of authorship agreements (i.e. the transfer of authorship rights) was further complicated in the 1978 Copyright Act, which envisaged a complicated procedure of determining the amount of remuneration for the broadcasting of non-stage music and literary works via radio and television. Pursuant to Article 57, it is no longer done by the author him/herself, given that several legal entities participate in the signing of the self-management agreement in connection with the remuneration (Article 57 para.3). This paragraph of Article 57 was repealed by the first article of the Act amending the Copyright Act of $1986 .{ }^{9}$

Nevertheless, far more significant changes to the Copyright Act were introduced by amendments in $1990^{10}$, not only owing to the technical and technological development but also due to changes in the socio-economic and political system of the country that this Act could not bypass. As a consequence of the first factor, there is a more detailed inclusion of computer programs in the legal framework; as a consequence of the second factor, companies are formed instead of associated labor organizations introduced by the previous law. In addition, it is significant that some copyright-related rights were regulated in more detail. This Act introduced the moral and property rights of performing artists (today's performers) into the legal text (Article 99). Inter alia, a performing artist is entitled: to have his/her name stated in any public presentation or performance of his work; to oppose the arbitrary modification, use, fragmentation or distribution of the recorded performance which contains technical or other defects or may undermine the performer's honour or reputation; to receive a remuneration; to explicitly prohibit audio-visual recording, reproduction, public presentation or performance, and broadcasting via radio or television without his/her permission (Article 99d-99g). Yet, a broadcasting organization may broadcast a performance without obtaining the performing artist's permission if it concluded an agreement with the artist (Article 99d); it may also record a performance without the artist's permission and paying the remuneration

\footnotetext{
${ }^{8}$ The Copyright Act, Official Journal of the SFRY, no. 19/1978.

${ }^{9}$ The Act amending the Copyright Act, Official Journal of the SFRY,no. 24/1986.

${ }^{10}$ The Act amending the Copyright Act, Official Journal of the SFRY, no. 21/1990.
} 
if it records the performance with its own means and only for its own broadcasting purposes (Article 99e). If a recorded performance is released for sale outside the primary use of broadcasting by radio or television, a contribution (fee) is paid to the performing artist's organizations (Article 99ž). When it comes to the copyright agreements with performing artists on recording performances and broadcasting recordings on the radio and television, these agreements also contain the specific number of broadcasts and the broadcasting period (Article 991). Furthermore, property rights under these agreements last for 20 years, while the artists' moral rights remain beyond that period (Articles 991j, 99m). Broadcasting organizations are obliged to inform performing artists' representatives about the use of the performance (Article 99o). Performing artists may also pursue the protection of their rights in a court of law (Article 99r).

\subsection{Act on Copyright and Related Rights of 1998}

This Act $^{11}$ was adopted in the period of the Federal Republic of Yugoslavia (FRY) and, as evidenced by its name, it had the form and content of the applicable law on this matter primarily due to the recognition and regulation of related rights. With regard to the property rights of authors, the exploitation of a copyrighted work also includes the right to broadcast, which does not differ significantly from what was provided by the previous act. The permission to broadcast is given by the author, and broadcasting (defined as the public communication of a work by wired or wireless transmission of electromagnetic, electrical and other signals at a distance) for the first time includes cable broadcasting; the Act also distinguishes between wired and wireless exploitation, except in two cases: if it is necessary for technical reasons, or if the broadcast caters for a smaller number of users (Article 27). For the first time in the legal framework on copyright, Article 27 also regulates and equates satellite broadcasting with broadcasting and cable broadcasting (as decoded signals under the control of the broadcasting company, or coded signals whose decoded form the broadcasting company can access), while broadcasting also encompasses the public communication of the work through wired and wireless means which enables individual access to a person whenever and wherever one chooses. The author also has the right to allow or prohibit the public communication of a work that is already being broadcast, or its broadcast simultaneously on the radio or television in a public place (Article 28). Similar to applicable legislation (which will be discussed later), this Act also encompassed restrictions on copyright in the form of suspension and legal license. Suspension of copyright is possible in case of reporting on current newsworthy events through the press, radio and television, provided that the work has already been published, that it is an integral part of the event, and that its used to an appropriate extent (Article 38). Article 44 also mentions the right of a broadcasting company to record a work on a sound or image carrier for broadcasting purposes, while Article 47 provides for the suspension of this right in case of broadcasting in shops or fairs for the purpose of demonstrating the operation of a television or radio. On the other hand, the legal license is mentioned in the context of radio and television indirectly, in terms of articles and photographs on current social issues, unless the author has explicitly prohibited them, and through broadcasting works from published phonograms (Articles 49, 51). Of course, this Act also envisages a copyright agreement as a way of assigning or transferring

\footnotetext{
${ }^{11}$ The Act on Copyright and Related Rights, Official Journal of the FRY, no. 24/1998.
} 
the author's copyright in its entirety, which indirectly refers to broadcasters as parties to that agreement. What is new in this Act is that its third part refers to related rights.

Just as copyright related to music, film and television programs is important for electronic media, importance is given to related rights based on these works (such as the rights of performers, phonogram and videogram producers) and related rights directly related to radio and television (the right of broadcast producers). In terms of broadcasting, the performer has the same moral and property rights as the author. We should mention the following property rights: recording and reproduction of recordings of the performance, circulating and renting, live broadcasting of the performance, and the public communication of the recorded performance. It should also be noted that the performer is denied the exclusive rights to broadcast the performance recorded and issued on a sound carrier or on a sound and image carrier, provided that the performer retains the right to participate in the profit made by renting a copy of the interpretation (Article 109). The rights of performers regarding the transfer of their rights by agreement are similar to the rights of authors, provided that the agreement relating to the broadcast of the performance contains both the number of broadcasts and the time when they may be broadcast (Article 113). The situation is similar when it comes to the rights of phonogram or videogram producers, who may allow or prohibit the reproduction, public communication, and renting of phonograms or videograms (Articles 119, 124).

The next four articles are very important for radio and television from the aspect of their rights, and they refer directly to these media as broadcast producers. For the purposes of this Act, "a broadcast is audio, visual, or audio-visual content which is converted into an electrical, electromagnetic or other types of signal, and broadcast for the purpose of its communication to the public" (Article 127). A broadcast producer is a person or entity that organized or provided the means for producing the broadcast, while a person that only broadcasts or rebroadcasts the broadcast will not be considered a broadcast producer (Article 128). The exclusive rights of the producer are related to the rebroadcasting of the broadcast, the recording of their broadcast on a sound or sound and picture carrier, the reproduction and marketing of those recordings, as well as their renting (Article 129). Almost the same provisions of this Act that apply to authors also apply to holders of related rights. However, while copyrights last for the life of the author and 50 years after his/her death and most related rights last for 50 years from the first publication (except for the rights of database producers), the rights of broadcast producers last much shorter - 20 years from the first protected broadcast (Article 138). All these rights are recognized if they originate in the territory of the FR Yugoslavia; they are also recognized to foreign persons on the basis of reciprocity or ratified international agreements (Article 141). Finally, the holders of these rights may claim judicial protection in civil litigation proceedings (Article 172).

\subsection{The Act on Copyright and Related Rights of 2004}

Following the democratic changes in 2000 and the changed name of the state in 2002 (The State Union of Serbia and Montenegro), the legislator adopted new Copyright and Related Rights Act. ${ }^{12}$ It seems that the adoption of the new Act was more a result of the need for discontinuity with the previous socio-political period, given that there were minimal changes in the structure of the law as compared to the previous one. However,

\footnotetext{
${ }^{12}$ The Act on Copyright and Related Rights, Official Gazette of Serbia and Montenegro, no. 61/2004.
} 
there were certain novelties, primarily in terms of certain technological measures; some of the novelties are directly or indirectly related to radio and television. The article referring to the right to broadcast was expanded with an item which states that, in case of rebroadcasting a broadcast belonging to another broadcasting company, copyrights are in the competence of the organization for the collective exercise of rights (Article 28). Also, when it comes to remuneration for the public communication of current events, photographs can no longer be subject to a legal license, but only newspaper articles, while the remunerations not paid if short excerpts from comments and articles are used (Article 54). However, the most significant change in the field of broadcasting is the content of the rights of broadcast producers, which is now extended to include the possibility to publicly communicate their broadcasts in places available to the public for a fee, as well as the possibility to make their programs interactively available to the public in a wired or wireless manner (Article 134). Also, one of the most significant changes to this law is the extension of copyright duration from 50 to 70 years after the author's death, which indirectly affected the extension of the broadcast producer's rights from 20 to 50 years (Article 144). Furthermore, Article 141 of the previous act was removed, which referred to the recognition of the right of foreign nationals only if they broadcast or rebroadcast the broadcast from the territory of the FRY. Finally, it is worth mentioning changes in the part related to the protection of copyright and related rights, as well as the expansion of the list of possible violations of these rights, primarily due to the application of new technological measures aimed at combating these violations (Article 150).

\section{The Positive LAW FRAMEWORK ON ELECTRONIC MEDIA IN THE COPYRIGHT AND RELATED RIGHTS ACT OF 2009}

\subsection{The Act on Copyright and Related Rights of 2009}

The current Copyright and Related Rights Act was passed in $2009,{ }^{13}$ and it underwent its most significant amendments in 2011, 2012, and 2019. The separation of Serbia and Montenegro, the creation of the Republic of Serbia, the new 2006 Constitution of RS, and the need for harmonizing Serbian legislation with EU law resulted in the adoption of the new legislative act. Although many provisions of this Act are identical to the previous act, we will focus on the provisions related to electronic media, which were amended in the new Act.

In Article 28 of this Act, which refers to the right to broadcast, the broadcasting companies are designated as broadcasting organizations (broadcasters); more importantly, rebroadcasting was removed from the last paragraph of this Article and moved to Article 29, which specifically regulates the right to rebroadcast. Under Article 29, the author has the exclusive right to allow or prohibit the rebroadcasting of the copyrighted work: 1)when the rebroadcasting is performed by a broadcasting organization other than the one that originally broadcast the work, and 2)when the communication to the public is performed via a cable or microwave system(cable broadcasting)or when the work is originally broadcast from another country (cable rebroadcasting), unless cable rebroadcasting is about the broadcast organization's own broadcast. It is also important that the right to a special remuneration no longer belonged to the broadcast producer (Article 146). One of the most extensive amendments to this Act refers to the collective exercise of copyright and related

\footnotetext{
${ }^{13}$ The Act on Copyright and Related Rights, Official Gazette of the Republic of Serbia (RS), no. 104/2009.
} 
rights, the organization of the collective exercise of rights, and the establishment of the Commission for Copyright and Related Rights (hereinafter: the Commission) which was in charge of determining the copyright tariff. Article 150 envisages the mandatory collective exercise of copyright and related rights when it comes to broadcasting and rebroadcasting of a copyrighted work. Broadcasting institutions are mentioned in two other articles of this law. Article 174 (item 3) envisages that the public broadcasting service institution concludes a special written agreement with the organizations for collective exercise of copyright and related rights, which jointly determine the copyright tariff, while other broadcasting organizations as users of copyrighted works are obliged to submit a list of programs which are the subject matter of copyright protection once a month (Article187, item 5) to the organizations for collective exercise of copyright and related rights. Therefore, collective organizations set tariffs on the use of copyrighted works; the tariffs apply to all broadcasting institutions, except for the public broadcasting service for which a special agreement is made.

\subsection{The Act amending the Act on Copyright and Related Rights of 2011}

Shortly after the adoption of the 2009 CRR Act, amendments were made, and this Act was adopted in 2011. ${ }^{14}$ The most significant changes for radio and television as electronic media are those related to the article on the expansion of the suspension of the authorship right when it comes to reporting on current newsworthy events. Thus, Article 12 allows the multiplication of copies of the published work, the preparation and reproduction of short extracts or digests from newspaper and other articles in press reviews, multiplication of public political, religious and other speeches, as well as the free use of daily information and news which have the nature of a newspaper report without the author's permission and without paying remuneration. In Article 22, which determines the content of the rights of the broadcast producer, the right to rebroadcast its broadcast is now specified and includes both wired and wireless broadcasting.

\subsection{The Act amending the Act on Copyright and Related Rights of 2012}

The 2012 amendments to the CRR Act ${ }^{15}$ mainly refer to the collective exercise of copyright and related rights, where the competence for determining the tariff for royalties has been transferred from the Commission to the Intellectual Property Office. The new Article 201d, which refers to electronic records of broadcasting and rebroadcasting, is important for the sphere of broadcasting. It prescribes the obligation of radio and television broadcasters to keep electronic records of broadcasts and rebroadcasts of copyrighted works and to be supervised by the Republic Broadcasting Agency, which has been entrusted to perform this duty in line with the regulatory acts provided byte Government.

\subsection{The Act on Amendments to the Acton Copyright and Related Rights of 2019}

The currently applicable version of the Act on Copyright and Related Rights(hereinafter: the CRR) was enacted in 2019. ${ }^{16}$ The novelties it brought are the result of both technical and technological progress, as well as the need for additional harmonization with EU law. These are provisions referring not only to computer programs and databases but also tissues of exercising

\footnotetext{
${ }^{14}$ The Act amending the Act on Copyright and Related Rights, Official Gazette RS, no. 99/2011.

15 The Act amending the Act on Copyright and Related Rights, Official Gazette RS, no. 119/2012.

${ }^{16}$ The Act amending the Act on Copyright and Related Rights, Official Gazette RS, no. 66/2019.
} 
and protecting copyright and related rights. However, there are significant amendments that apply to radio and television as electronic media, which will be presented here.

The article relating to the right to broadcast has again undergone changes, as has the next article relating to rebroadcasting. A new article related to satellite broadcasting has been added. Article $28 \mathrm{CRR}$, dealing with the right to broadcast, is now simplified; in addition to stating the author's exclusive right to allow or prohibit broadcasting, it defines broadcasting as "the communication of an author's work to the public by the transmission of radio or television program signals from the broadcasting entity (hereinafter: the broadcasting organization) to receiving devices via a network of transmitters (terrestrial broadcasting), cable distribution systems (cable broadcasting), or satellite stations (satellite broadcasting)." (Article $6 \mathrm{CRR}$ ). The new article refers to satellite broadcasting in the Republic of Serbia. This article explains the term satellite and copies the term satellite broadcasting and signal decoding from the previous version of the Act, with the addition that satellite broadcasting exists when signals come from a country that has a lower level of protection than prescribed by this law, but provided the transmitter is on the territory of Serbia, or if a broadcasting organization established or based in our country has ordered the introduction of these signals (Article 7 CRR). In addition to the right to rebroadcast, the next article also regulates cable rebroadcasting. In case of cable rebroadcasting, the author exercises the right exclusively through collective organizations, unless the broadcasting organization is entitled to the rebroadcast program (Article $8 \mathrm{CRR}$ ). Article 8 also envisages the role of a mediator if the broadcasting organization and the cable operator do not reach an agreement on the conditions of rebroadcasting. The mediator submits to the interested parties a proposal for resolving the dispute, including a period of three months to reject the solution; otherwise, the proposal will be considered accepted. The rights of performers have also been expanded (and extended from 50 to 70 years); thus, the right to permit or ban broadcasting and rebroadcasting does not only apply to a recording published on a sound carrier but also on a sound and image carrier. The rights of phonogram producers have also been expanded, determining for its users in more detail the procedure of collecting a single fee with the mediation of the organization for the collective exercise of these rights (Articles 20 and 23 CRR). Therefore, performers are remunerated by both television and cable broadcasters. Article 24 CRR, which refers to the rights of broadcast producers, is also important. With regards to recording and reproduction as a right relating to broadcast producers, the Act does not distinguish whether it is a wireless, wired, cable, or satellite broadcast, although the cable operator does not have the right to record its broadcast if it only retransmits the broadcasts of broadcasting organizations via cable (Article 25 CRR).

\section{CONCLUSION}

Observing the protection of rights related to electronic media through national copyright laws, it may be noticed that the dynamic is conditioned by technical and technological development. Using a normative analysis of all copyright laws enacted from the first legislative act in 1929 to the currently valid one, this dynamic is easily noticeable. In the first phase of legislative development, electronic media were viewed exclusively through the protection that authors needed to be provided, i.e. through the rights that authors had in the framework of the public communication of their works on radio and television. The 
second phase of development of the national legislation related to the electronic media norms arises not only from the expansion of the scope of copyright protection but also from the establishment and development of related rights. This phase extends this protection to new categories of holders of related rights: performers, phonogram producers, videogram producers, and radio and television as holders of rights to the protection against unauthorized broadcasting and rebroadcasting, as well as holders of other rights they have as producers of broadcasts. As for the electronic media rights concerning their programs, protection has been secured for terrestrial broadcasting, cable broadcasting, and satellite broadcasting.

The question is whether copyright norms relating to radio and television as electronic media have reached a satisfactory level of protection, or whether there is still room for improvement. Given the progressive development of technology and the widespread convergence of the media, it is likely that the copyright protection in prospective legislation will be directed towards more modern forms of media. Yet, being the dominant media today, radio and television still bear great importance in the field of copyright.

\section{REFERENCES}

BBC Group (2020):Annual Report and Accounts 2019/20, available at www.bbc.co.uk/annualreport, http://downloads.bbc.co.uk/aboutthebbc/reports/annualreport/2019-20.pdf, (accessed 5.10.2020)

Cvetkovski, T., (2013), Copyright and Popular Media - Liberal Villains and Technological Change, Palgrave Macmillan, London, UK.

Pustišek, I., (1987), Istorija zakonodavstva o radiodifuziji u Jugoslaviji (The History of Broadcasting Legislation in Yugoslavia), Savremena administracija, Beograd

\section{LEGISLATIVE ACTS}

Закон о електронским медијима (The Electronic Media Act), Службени гласник PC, бр.83/2014 и 6/2016др.закон, http://www.rem.rs/sr/regulativa/zakonska-regulativa/zakon-o-elektronskim-medijima\#gsc.tab=0, (accessed on 6.10.2020)

Закон о заштити ауторског права (The Copyright Protection Act), Службене новине Краљевине Југославије, бр. 304/1929; (accessed on 6.10.2020), http://www.zis.gov.rs/upload/documents/pdf_sr/pdf/propisi/Zakon\% 20o\%20zastiti\%20autorskog\%20prava\%201930-min.pdf

Закон о заштити ауторског права (The Copyright Protection Act), Службени лист Федеративне Народне Републике Југослафије (ФНРЈ), бр. 45/1946; (accessed on 6.10.2020), http://www.zis.gov.rs/upload/ documents/pdf_sr/pdf/propisi/\%20\%D0\%BE\%20\%D0\%B7\%D0\%B0\%D1\%88\%D1\%82\%D0\%B8\%D1\% $82 \% \mathrm{D} 0 \% \mathrm{~B} 8 \% 20 \% \mathrm{D} 0 \% \mathrm{~B} 0 \% \mathrm{D} 1 \% 83 \% \mathrm{D} 1 \% 82 \% \mathrm{D} 0 \% \mathrm{BE} \% \mathrm{D} 1 \% 80 \% \mathrm{D} 1 \% 81 \% \mathrm{D} 0 \% \mathrm{BA} \% \mathrm{D} 0 \% \mathrm{BE} \% \mathrm{D} 0 \% \mathrm{~B} 3$ $\% 20 \% \mathrm{D} 0 \% \mathrm{BF} \% \mathrm{D} 1 \% 80 \% \mathrm{D} 0 \% \mathrm{~B} 0 \% \mathrm{D} 0 \% \mathrm{~B} 2 \% \mathrm{D} 0 \% \mathrm{~B} 0 \% 201946 \% 20 \% \mathrm{D} 0 \% \mathrm{~A} 1 \% \mathrm{D} 0 \% 9 \mathrm{~B} \% 20 \% \mathrm{D} 0 \% \mathrm{~A} 4 \%$ D0\%9D\%D0\%A0\%D0\%88.pdf

Закон о ауторском праву (The Copyright Act), Службени лист ФНРЈ, бр. 36/1957; http:/www.zis.gov.rs/ upload/documents/pdf_sr/pdf/propisi/Zakon\%20o\%20autorskom\%20pravu\%201957-min.pdf, (accessed on 6.10.2020)

Закон о изменама и допунама Закона о ауторском праву (The Act amending the Copyright Act), Службени лист Социјалистичке Федеративне Репулике Југославије (СФРЈ), бр. 11/1965.

Закон о ауторском праву (The Copyright Act), Службени лист СФРЈ, бр. 30/1968; http://www.zis.gov.rs/ upload/documents/pdf_sr/pdf/propisi/Zakon\%20o\%20autorskom\%20pravu\%201968\%20SL\%20SFRJmin.pdf, (accessed on 6.10.2020)

Закон о ауторском праву (The Copyright Act), Службени лист СФРЈ, бр. 19/1978, http://www.zis.gov.rs/ upload/documents/pdf_sr/pdf/propisi/Zakon\%20o\%20autorskom\%20pravu\%201978\%20SL\%20SFRJmin.pdf, (accessed on 6.10.2020)

Закон о изменама и допунама Закона о ауторском праву (The Act amending the Copyright Act), Службени лист СФРЈ, бр. 24/1986, (accessed on 6.10.2020), http://www.zis.gov.rs/upload/documents/pdf_sr/pdf/ 
propisi/Zakon\%20o\%20izmenama\%20i\%20dopunama\%20Zakona\%20o\%20autorskom\%20pravu\%201986 $\%$ 20SL\%20SFRJ-min.pdf

Закон о изменама и допунама Закона о ауторском праву (The Act amending the Copyright Act), Службени лист СФРЈ, бр. 21/1990, (accessed on 6.10.2020), http://www.zis.gov.rs/upload/documents/pdf_sr/pdf/ propisi/Zakon\%20o\%20izmena\%20i\%20dopunama\%20Zakona\%20o\%20autorskom\%20pravu\%201990\% 20SL\%20SFRJ-min.pdf

Закон о ауторском и сродним правима (The Act on Copyright and Related Rights), Службени лист Савезне Републике Југославије (СРJ), бр. 24/1998, http://www.zis.gov.rs/upload/documents/pdf_sr/pdf/propisi/ Zakon_o_autorskim_i_srodnim_pravima_1998_SL_SRJ_compressed (1)[1].pdf, (accessed on 6.10.2020)

Закон о ауторском и сродним правима (The Act on Copyright and Related Rights), Службени лист Државнезаједнице Србије и Црне Горе (СЦГ), бр. 61/2004, (accessed on 6.10.2020), http://www.zis.gov. rs/upload/documents/pdf_sr/pdf/propisi/Zakon_o_autosrkim_i_srodnim_pravima_2004_SL_SCG_compres sed[1].pdf

Закон о ауторском и сродним правима (The Act on Copyright and Related Rights), Службени гласник Републике Србије (РC), бр. 104/2009, (accessed on 6.10.2020), http://www.zis.gov.rs/upload/documents/ pdf_sr/pdf/propisi/Zakon_o_autorskim_i_srodnim_pravima_2009_SG_RS_compressed_(1)[1].pdf

Закон о изменама и допунама Закона о ауторском и сродним правима (The Act amending the Act on Copyright and Related Rights), Службени гласник PC, бр. 99/2011, (access 6.10.2020) http://www.zis.gov.rs/upload/documents/pdf_sr/pdf/propisi/Zakon\%20o\%20izmenama\%20i\%20dopunama $\% 20$ Zakona\%20o\%20autorskim\%20i\%20srodnim\%20pravima\%202011\%20SG\%20RS-min.pdf

Закон о изменама и допунама Закона о ауторском и сродним правима (The Act amending the Act on Copyright and Related Rights), Службени гласник РC, бр. 119/2012

Закон о изменама и допунама Закона о ауторском и сродним правима (The Act amending the Act on Copyright and Related Rights), Службени гласник PC, бр. 66/2019, http://www.zis.gov.rs/upload/ documents/pdf_sr/pdf/propisi/\%20\%D0\%BE\%20\%D0\%B8\%D0\%B7\%D0\%BC\%D0\%B5\%D0\%BD\%D0 $\% \mathrm{~B} 0 \% \mathrm{D} 0 \% \mathrm{BC} \% \mathrm{D} 0 \% \mathrm{~B} 0 \% 20 \% \mathrm{D} 0 \% \mathrm{~B} 8 \% 20 \% \mathrm{D} 0 \% \mathrm{~B} 4 \% \mathrm{D} 0 \% \mathrm{BE} \% \mathrm{D} 0 \% \mathrm{BF} \% \mathrm{D} 1 \% 83 \% \mathrm{D} 0 \% \mathrm{BD} \% \mathrm{D} 0 \% \mathrm{~B} 0$ $\% \mathrm{D} 0 \% \mathrm{BC} \% \mathrm{D} 0 \% \mathrm{~B} 0 \% 20 \% \mathrm{D} 0 \% 97 \% \mathrm{D} 0 \% \mathrm{~B} 0 \% \mathrm{D} 0 \% \mathrm{BA} \% \mathrm{D} 0 \% \mathrm{BE} \% \mathrm{D} 0 \% \mathrm{BD} \% \mathrm{D} 0 \% \mathrm{~B} 0 \% 20 \% \mathrm{D} 0 \% \mathrm{BE} \% 20$ $\% \mathrm{D} 0 \% \mathrm{~B} 0 \% \mathrm{D} 1 \% 83 \% \mathrm{D} 1 \% 82 \% \mathrm{D} 0 \% \mathrm{BE} \% \mathrm{D} 1 \% 80 \% \mathrm{D} 1 \% 81 \% \mathrm{D} 0 \% \mathrm{BA} \% \mathrm{D} 0 \% \mathrm{~B} 8 \% \mathrm{D} 0 \% \mathrm{BC} \% 20 \% \mathrm{D} 0 \% \mathrm{~B} 8 \%$ $20 \% \mathrm{D} 1 \% 81 \% \mathrm{D} 1 \% 80 \% \mathrm{D} 0 \% \mathrm{BE} \% \mathrm{D} 0 \% \mathrm{~B} 4 \% \mathrm{D} 0 \% \mathrm{BD} \% \mathrm{D} 0 \% \mathrm{~B} 8 \% \mathrm{D} 0 \% \mathrm{BC} \% 20 \% \mathrm{D} 0 \% \mathrm{BF} \% \mathrm{D} 1 \% 80 \% \mathrm{D} 0 \% \mathrm{~B}$ 0\%D0\%B2\%D0\%B8\%D0\%BC\%D0\%B0\%202019\%20\%D0\%A1\%D0\%93\%20\%D0\%A0\%D0\%A1.pdf, (accessed on 6.10.2020)

\section{RAZVOJ PRAVA U VEZI SA ELEKTRONSKIM MEDIJIMA KROZ ZAKONSKE PROPISE O AUTORSKOM PRAVU U SRBIJI}

Rad ima za cilj da prikaže razvoj domaće regulative o autorskom i srodnim pravima u oblasti radiodifuzije, odnosno autorskopravnih normi koje se direktno odnose na elektronske medije. To ce se učiniti hronološkim putem, normativnom analizom svih zakonskih propisa o autorskom i srodnim pravima donetim na prostorima nekadašnje Jugoslavije pa do zakonskih propisa Republike Srbije. Nakon polaznih premisa, uslediće analiza normi u vezi sa elektronskim medijima (radijom i televizijom) od usvajanja prvog Zakona o autorskom pravu 1929. godine, pa do Zakona o autorskom i srodnim pravima iz 2004. godine. Na kraju, daće se pregled autorskopravnih normi u vezi sa elektronskim medijima u pozitivnom pravu, kroz analizu Zakona o autorskom i srodnim pravima iz 2009. godine, uz važeće izmene i dopune. Rezultat ove analize trebalo bi da ukaže na značaj koji su elektonski mediji imali na zakonodavca kroz istoriju regulisanja autorskog prava, ali i na značaj ovih medija u važećem autorskom pravu.

Ključne reči: elektronski mediji, radio, televizija, autorsko pravo, Zakon o autorskom i srodnim pravima 